\title{
RESPONSE SURFACE MODELING OF PHYSICAL AND MECHANICAL PROPERTIES OF COTTON SLUB YARNS
}

\author{
Muhammad Bilal Qadir ${ }^{1,2}$, Zulfiqar Ali Malik ${ }^{2^{*}}$, Usman Ali $^{3}$, Amir Shahzad $^{2}$, Tanveer Hussain ${ }^{2}$, \\ Amir Abbas ${ }^{3}$, Muhammad Asad ${ }^{3}$, Zubair Khaliq ${ }^{1,2 *}$ \\ 1'Department of Organic and Nano Engineering, Hanyang University, Seoul, South Korea \\ ${ }^{2}$ Faculty of Engineering \& Technology, National Textile University, Faisalabad, Pakistan. \\ ${ }^{3}$ Technical Textile Research Group, College of Textile Engineering, Bahauddin Zakariya University, Multan, Pakistan. \\ Email: drzulfiqarali70@gmail.com;zubntu@yahoo.com
}

\begin{abstract}
:
The objective of this study was to model the physical and mechanical properties of $100 \%$ cotton slub yarns commonly used in denim and other casual wear. Statistical models were developed using central composite experimental design of the response surface methodology. Yarn's linear density, slub thickness, slub length and pause length were used as the key input variables while yarn strength, elongation, coefficient of mass variation, imperfections and hairiness were used as response/output variables. It was concluded that yarn strength and elongation increased with increase in linear density and pause length, and decreased with increase in slub thickness and slub length. Yarn mass variation and total imperfections increased with increase in slub thickness and pause length, whereas yarn imperfections and hairiness decreased with increase in slub length. It was further concluded that due to statistically significant square and interaction effects of some of the input variables, only the quadratic model instead of the linear models can adequately represent the relationship between the input and the output variables. These statistical models will be of great importance for the industrial personnel to improve their productivity and reduce sampling.
\end{abstract}

\section{Keywords:}

Modeling, fancy, slub, mechanical properties, cotton ring spun yarn

\section{Introduction}

Fancy yarns comprise a class of specialty textile yarns with intentionally induced irregular physical characteristics such as diameter, bulk, color, and so on. Fancy yarns are used for obtaining different interesting appearances and aesthetic characteristics in high-fashion clothing including denim, curtains, carpets, upholstery fabrics, and so on. [1-4]

Slub yarn is a type of fancy yarn in which slubs (i.e., thick places in the yarns) are produced by systematically changing yarn's linear density during the spinning process. [5] These slub yarns with many variations are widely used in denim garments to give special looks and aesthetic effects. [6] Different aspects of slub yarns have been investigated by the researchers in the past. Liu et al. has demonstrated an accurate and rapid approach for automatically measuring slubs. [7]. Testore et al. studied the relationship of basic parameters of slub yarn with the resultant yarn's appearance. [8] Lu et al. investigated the influence of yarn twist on the mechanical and physical properties of the slub yarn and concluded that the slub length is a key factor to decide the yarn twist. [9] Some mechanical properties of slub yarn have been analyzed using statistical methods. [4] It has been reported that the twist distribution in every section of slub yarn is inversely proportional to the square of linear density of the corresponding section. [9] The parameters of rotor spun slub yarn were investigated and it was found that rotor diameter, yarn count, slub thickness and performance of the servomotor significantly affect the slub length. [10]

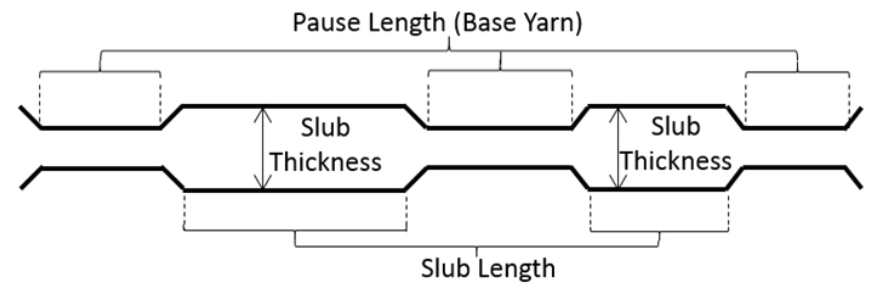

Figure 1. Structure of slub yarn.

The important parameters of slub yarn include the slub length, slub distance (pause length/base yarn), mass increase or mass decrease within a slub (slub thickness) or within a pause (pause thickness) and the repetition pattern of the slub yarn as shown in Figure 1. Different practical methods are available to determine the repetition pattern of the slub yarn, including the use of a black board and Uster mass diagram report shown in Figure 2. [11, 12]

The literature review does not reveal any model that characterizes the effect of key slub parameters on the resulting yarn characteristics. This paper endeavors to fill this gap and attempts to model some of the key physical and mechanical properties of the $100 \%$ cotton slub yarn. The range of linear densities covered in this study corresponds to the slub yarns commonly used for making denim fabrics. The design of experiment is based on the response surface methodology (RSM) and the central composite design (CCD) has been 
(a)

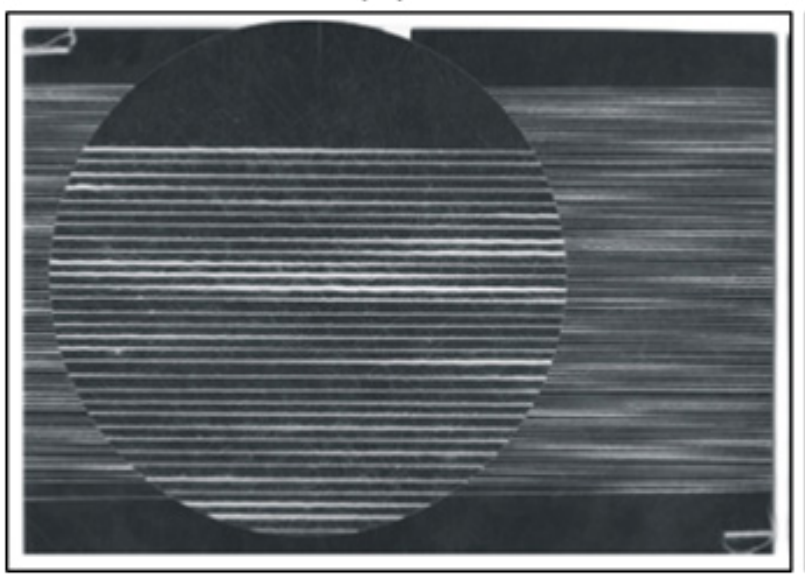

(b)

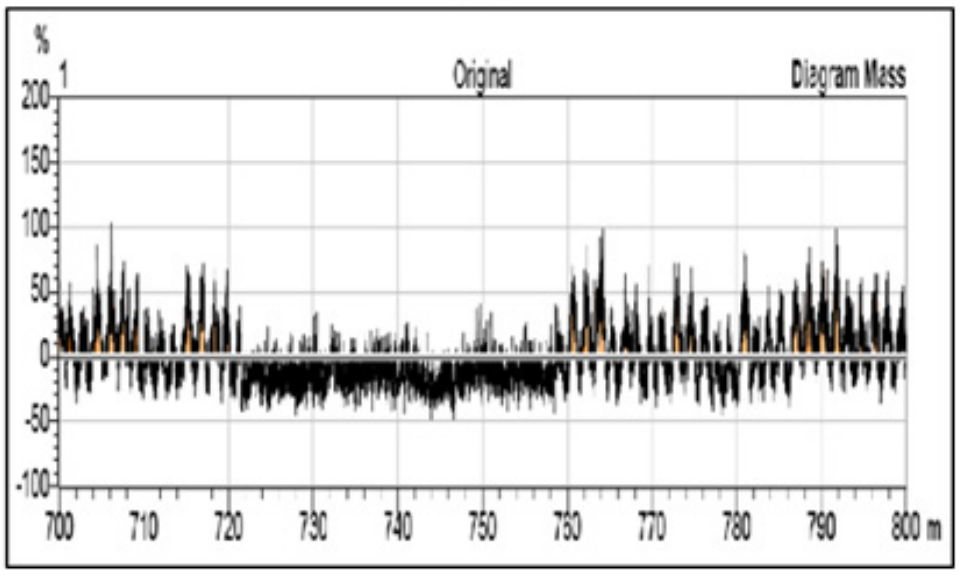

Figure 2. Repetition pattern of slub yarn: (a) On black board, (b) On Uster mass diagram.

employed to cover not only the linear effects but also the quadratic effects of key slub parameters on the resulting physical and mechanical properties of the yarn.

\section{Experimental}

\section{$\underline{2.1 \text { Materials \& methods }}$}

Pakistani cotton variety NIAB 999 was used to make $100 \%$ cotton slub yarn for this study. The properties of cotton fibers, as determined on a High Volume Instrument USTER HVI SPECTRUM, are given in Table 1. Cotton fibers were processed in the blow room (Trutzschler 2001) and carding (DK-903, Trutzschler) section of a spinning mill. Slivers obtained from the carding machines were given two drawing passages on the draw-frames (DX-8, Toyoda \& RSB D-22, Rieter) to get more uniform slivers of $4.53 \mathrm{gram} / \mathrm{meter}$. The drawn slivers were processed through the roving machine (FL-16, Toyoda) to get roving linear density of 842.85 tex at the flyer speed of 950 rpm, and twist level of 33.47 twist/meter. The roving was then spun into slub yarns having average linear densities of 98.33 , $84.28,73.75,65.55$ and 59 tex, with twist level of 463, 499, 534, 567 and 597 twists/meter. Caipo CSTU slub attachment with Toyoda RY ring frame was used to make all the slub yarn samples for this study. The slub yarn factors and their levels are given in Table 2 .

For all the samples, break draft was 1.34 , roller gauge 44-51 $\mathrm{mm}$, ring traveler number C-1HW DR \# 9, ring diameter 45 $\mathrm{mm}$, spindle speed $10000 \mathrm{rpm}$ and machine lift $20.32 \mathrm{~cm}$. Ring bobbins of the produced yarns were conditioned under standard atmospheric conditions according to ISO 139:2005 before testing for unevenness, imperfections, and hairiness on USTER TESTER-4 as per ISO 16549:2004 and yarn strength and elongation at break on USTER TENSORAPID-3 according to ISO 2062:1993 standard method. For authentic results, intensive sampling was carried out. 20 yarn bobbins were randomly selected from 120 bobbins for each level of experiment and each result is an average of 60 readings taken from 20 samples.
Table 1. Properties of cotton used in this study

\begin{tabular}{|l|c|c|}
\hline Properties & Units & Values \\
\hline Spinning Consistency Index & Index & 125 \\
\hline Micronaire & $\mu \mathrm{g} / \mathrm{meter}$ & 190.16 \\
\hline Staple Length (UHML) & $\mathrm{mm}$ & 27.5 \\
\hline Uniformity Index & Index & 82.6 \\
\hline Short Fiber Index (SFI) & $\%$ & 8.4 \\
\hline Strength & $\mathrm{g} / \mathrm{tex}$ & 30.1 \\
\hline Elongation & $\%$ & 5.3 \\
\hline Moisture content & $\%$ & 8.5 \\
\hline Degree of Reflectance & Rd value & 72.5 \\
\hline Degree of Yellowness & $+\mathrm{b}$ value & 8.8 \\
\hline Nep Count per gram & cnt/g & 154 \\
\hline Seed coated neps & cnt/g & 20 \\
\hline Maturity Index & Index & 0.97 \\
\hline
\end{tabular}

\section{Results and discussion}

\subsection{Statistical Analysis}

The statistical software Minitab-17 was used for the central composite design (CCD) and analysis of the experiments as well as to develop the response surface regression models for predicting the selected yarn parameters (i.e., yarn strength, elongation $\%, \mathrm{CV}_{\mathrm{m}}, \mathrm{IPI}$ and hairiness). Table 3 gives the complete central composite design used in this study and values of the yarn parameters obtained after experimentation. Analysis of variance (ANOVA) was performed to evaluate the statistical significance of model terms. A higher value of coefficient indicates a higher effect of corresponding term and vice versa. A minus (-) sign indicates that the response increases by decreasing the factor value and vice versa. 
Table 2. Experimental factors and their levels in coded and uncoded units

\begin{tabular}{|c|c|c|c|c|c|c|c|c|}
\hline \multirow{2}{*}{ No. } & \multirow{2}{*}{ Factors } & \multirow{2}{*}{ Factors ID } & \multirow{2}{*}{ Units } & \multicolumn{5}{|c|}{ Levels } \\
\hline & & & & -2 & -1 & 0 & +1 & +2 \\
\hline 1 & $\begin{array}{l}\text { Linear Density } \\
\text { (LD) }\end{array}$ & $x_{1}$ & Tex & 98.5 & 84.4 & 73.9 & 65.7 & 59.1 \\
\hline 2 & $\begin{array}{c}\text { Slub Thickness } \\
\text { (ST) }\end{array}$ & $x_{2}$ & $\%$ & 140 & 170 & 200 & 230 & 260 \\
\hline 3 & $\begin{array}{l}\text { Slub Length } \\
\text { (SL) }\end{array}$ & $x_{3}$ & $\mathrm{~cm}$ & 6 & 8 & 10 & 12 & 14 \\
\hline 4 & $\begin{array}{l}\text { Pause Length } \\
\text { (PL) }\end{array}$ & $x_{4}$ & $\mathrm{~cm}$ & 5 & 20 & 35 & 50 & 65 \\
\hline
\end{tabular}

Table 3. Summary of the experimental results

\begin{tabular}{|c|c|c|c|c|c|c|c|c|c|}
\hline \multirow[b]{2}{*}{ EXP \# } & \multicolumn{4}{|c|}{ INPUT FACTORS / SLUB PARAMETERS } & \multicolumn{5}{|c|}{ OUTPUT YARN PARAMETERS } \\
\hline & $\begin{array}{c}\text { Yarn } \\
\text { Linear } \\
\text { Density }\end{array}$ & $\begin{array}{c}\text { Slub } \\
\text { thickness }\end{array}$ & $\begin{array}{c}\text { Slub } \\
\text { length }\end{array}$ & $\begin{array}{l}\text { Pause } \\
\text { length }\end{array}$ & $\begin{array}{c}\text { Yarn } \\
\text { Strength }\end{array}$ & Elongation & $\begin{array}{l}\text { Yarn } \\
\mathrm{CV}_{\mathrm{m}}\end{array}$ & Total IPI & $\begin{array}{l}\text { Hairiness } \\
\text { index }\end{array}$ \\
\hline & $($ Tex $)$ & $(\%)$ & $(\mathrm{cm})$ & $(\mathrm{cm})$ & $(\mathrm{cN} / \mathrm{tex})$ & $\%$ & $(\%)$ & & \\
\hline 1 & 65.7 & 170 & 8 & 20 & 885 & 6.4 & 28.5 & 1354.5 & 9.5 \\
\hline 2 & 84.4 & 230 & 8 & 20 & 990 & 6.8 & 43.8 & 5245.5 & 11.8 \\
\hline 3 & 84.4 & 170 & 12 & 20 & 1125 & 7.1 & 28.7 & 838.5 & 10.8 \\
\hline 4 & 65.7 & 230 & 12 & 20 & 720 & 4.7 & 43.8 & 7738.5 & 10.4 \\
\hline 5 & 84.4 & 170 & 8 & 50 & 1210 & 7.3 & 25.0 & 1251.5 & 10.3 \\
\hline 6 & 65.7 & 230 & 8 & 50 & 876 & 5.5 & 41.0 & 1903.5 & 9.5 \\
\hline 7 & 65.7 & 170 & 12 & 50 & 935 & 6.0 & 28.0 & 1019.5 & 9.3 \\
\hline 8 & 84.4 & 230 & 12 & 50 & 1055 & 7.1 & 43.3 & 2036.5 & 11.5 \\
\hline 9 & 73.9 & 200 & 10 & 35 & 951 & 6.2 & 36.2 & 2228.0 & 10.4 \\
\hline 10 & 73.9 & 200 & 10 & 35 & 950 & 6.3 & 36.1 & 2248.0 & 10.2 \\
\hline 11 & 84.4 & 170 & 8 & 20 & 1130 & 7.0 & 28.3 & 1325.5 & 10.9 \\
\hline 12 & 65.7 & 230 & 8 & 20 & 780 & 5.6 & 43.9 & 5611.0 & 9.7 \\
\hline 13 & 65.7 & 170 & 12 & 20 & 890 & 6.2 & 29.0 & 1014.0 & 9.3 \\
\hline 14 & 84.4 & 230 & 12 & 20 & 970 & 6.1 & 43.5 & 7303.0 & 11.5 \\
\hline 15 & 65.7 & 170 & 8 & 50 & 945 & 6.2 & 25.5 & 1281.0 & 9.3 \\
\hline 16 & 84.4 & 230 & 8 & 50 & 1120 & 6.6 & 40.6 & 1865.5 & 10.7 \\
\hline 17 & 84.4 & 170 & 12 & 50 & 1200 & 6.8 & 27.0 & 981.5 & 10.0 \\
\hline 18 & 65.7 & 230 & 12 & 50 & 823 & 5.7 & 44.7 & 2235.0 & 9.6 \\
\hline 19 & 73.9 & 200 & 10 & 35 & 953 & 6.3 & 36.4 & 2225.5 & 10.2 \\
\hline 20 & 73.9 & 200 & 10 & 35 & 952 & 6.2 & 36.1 & 2213.0 & 10.3 \\
\hline 21 & 98.5 & 200 & 10 & 35 & 1259 & 7.0 & 36.0 & 2101.0 & 12.5 \\
\hline 22 & 59.1 & 200 & 10 & 35 & 826 & 6.5 & 36.1 & 2356.0 & 9.3 \\
\hline 23 & 73.9 & 140 & 10 & 35 & 1094 & 7.1 & 19.0 & 175.5 & 9.3 \\
\hline 24 & 73.9 & 260 & 10 & 35 & 833 & 6.1 & 51.1 & 4413.0 & 11.1 \\
\hline 25 & 73.9 & 200 & 6 & 35 & 1083 & 7.3 & 32.5 & 2482.5 & 10.2 \\
\hline 26 & 73.9 & 200 & 14 & 35 & 989 & 7.2 & 37.8 & 2350.5 & 10.4 \\
\hline 27 & 73.9 & 200 & 10 & 5 & 715 & 5.8 & 27.3 & 6864.0 & 10.4 \\
\hline 28 & 73.9 & 200 & 10 & 65 & 1032 & 7.3 & 32.8 & 1430.0 & 9.9 \\
\hline 29 & 73.9 & 200 & 10 & 35 & 954 & 6.3 & 35.7 & 2175.0 & 10.3 \\
\hline 30 & 73.9 & 200 & 10 & 35 & 951 & 6.4 & 35.9 & 2195.0 & 10.3 \\
\hline
\end{tabular}


The quadratic models for predicting various yarn parameters, comprising only the statistically significant terms, are given in Table 4. R-sq value indicates how much variation in the output yarn parameter is explained by the model. The higher the R-sq, the better the model fits the data.

\subsection{Effect of Slub Parameters on Yarn Strength}

The statistical analysis given in Table 4 reveals that the slub yarn strength mainly depends on slub length (coeff. $=-73.2$ ) followed by pause length (coeff. $=9.94$ ), yarn linear density (coeff. $=6.33$ ) and slub thickness (coeff. $=-0.25$ ). Please see Figure 3 for illustration of effect of yarn linear density, pause length, slub thickness and slub length on the slub yarn's strength.

It is clear that slub yarn's strength increases by decreasing slub length and slub thickness but decreases by decreasing the yarn linear density and pause length. It can be further noticed from the statistical analysis and response surface plots that the effects of slub length and pause length are not linear. The curvature effect is represented by the statistically significant square values like $X_{3}^{2}(P$-value $=0.000)$ and $X_{4}^{2}$ $(P$-value $=0.000)$ respectively, as given in Table 5 . The yarn strength decreases with the increase of slub length up to a certain level after which there is no further decrease in yarn strength by increasing the slub length. Similarly, yarn strength first increases steadily by increasing the pause length up to a certain level, after which there is no further increase in yarn strength by increasing the pause length.
The effect of linear density and slub thickness on yarn strength was found to be linear. The trend in the results of the effect of different slub parameters on yarn strength can be explained as follows.

As the yarn linear density decreases, diameter of yarn also decreases and consequently, the number of fibers per cross section decreases. So the yarn strength decreases for lower yarn linear density due to less number of fibers per cross section $[13,14]$ and consequently, less cohesive forces between the fibers. Slub is the self-generated thick place with specific length and thickness. A "pause" is the distance between two consecutive slubs with specific length. [8] The number of fibers in the slub portion is greater than that of the base yarn (i.e., pause portion) even though both portions have the same set of Twist Multipliers (TM). However, in actual twisting process, polar moment of inertia and torsional rigidity of the two portions have great difference due to the diameter difference. So the twist inserted in the slub portion (of larger diameter) is always less as compared to that in the pause portion (of lower diameter). [9]. As the yarn strength mainly depends on the twist of the yarn, [15] so by increasing the slub thickness and slub length, twist in the slub portion decreases; due to which, overall strength of the yarn also decreases. By increasing the pause length, the strength of yarn increases because the relative length of pause portion with higher twist increases in the yarn. However, the strength of cotton yarn increases with an increase of twist up to a certain point, beyond which, the strength and elongation of yarn tend to decrease. When twist in the base yarn (i.e., pause portion) reaches its maximum point, the twist shifts towards the

Table 4. Quadratic models (coded) for predicting the output yarn parameters

\begin{tabular}{|l|c|c|}
\hline $\begin{array}{l}\text { Output yarn } \\
\text { parameters }\end{array}$ & Response surface modelling Equations & R-Sq \\
\hline Strength & $681+6.33 X_{1}-0.25 X_{2}-73.2 X_{3}+9.94 X_{4}+0.0394 X_{12}+5.08 X_{32}-0.0902 X_{42}-0.185 X_{2} X_{3}$ & $97.47 \%$ \\
\hline Elongation & $9.19+.0416 X_{1}-0.0091 X_{2}-0.881 X_{3}+0.0115 X_{4}+0.0421 X_{32}$ & $64.73 \%$ \\
\hline Unevenness & $-26.59-0.0152 X_{1}+0.2622 X_{2}+0.461 X_{3}+0.4010 X_{4}-0.0059 X_{42}$ & $96.96 \%$ \\
\hline Imperfections & $-8971-8.02 X_{1}+70.1 X_{2}-949 X_{3}+342.3 X_{4}+2.1 X_{42}+6.3 X_{2} X_{3}-2.48 X_{2} X_{4}-7.1 X_{3} X_{4}$ & $97.27 \%$ \\
\hline Hairiness & $6.64+0.0767 X_{1}-0.0094 X_{2}-0.403 X_{3}-0.0135 X_{4}+0.0022 X_{2} X_{3}$ & $93.17 \%$ \\
\hline
\end{tabular}

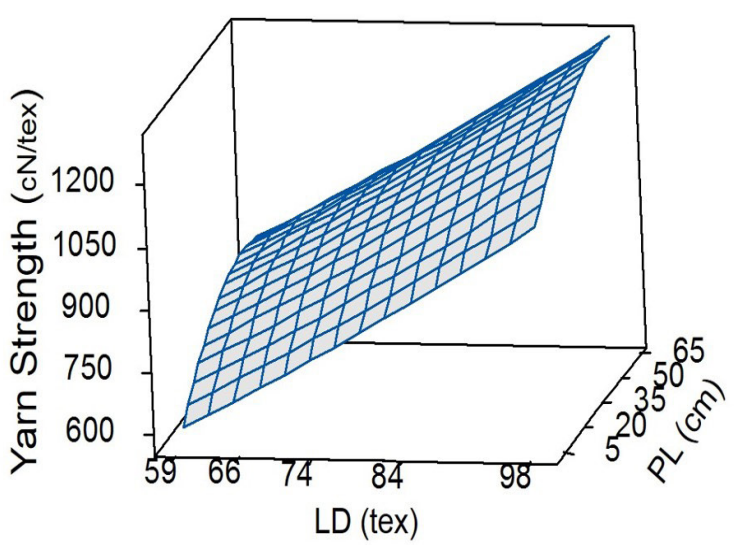

LD (tex)

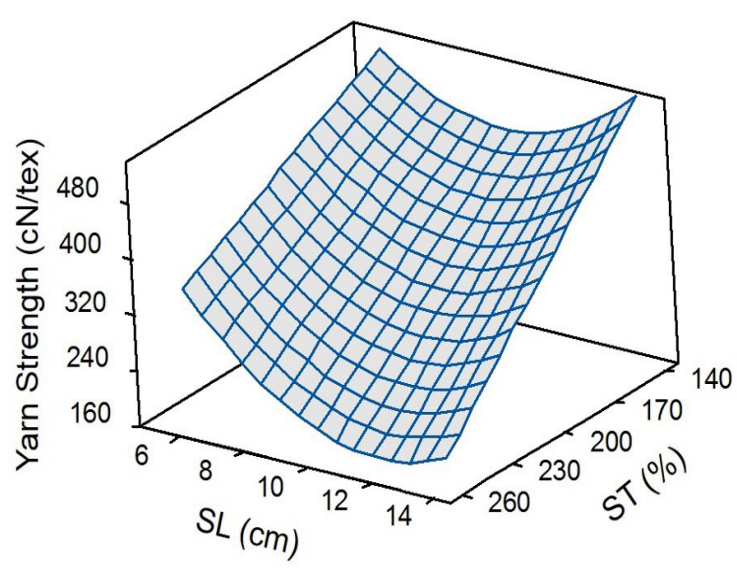

140

Figure 3. Response surface plots for yarn strength. 
Table 5. Estimated coefficients (coded) and P-values of significant input variables for different output yarn parameters

\begin{tabular}{|l|c|c|c|c|c|c|c|c|c|c|}
\hline & \multicolumn{2}{|c|}{ Yarn Strength } & \multicolumn{2}{|c|}{ Elongation } & \multicolumn{2}{|c|}{$\mathbf{C V}_{\mathbf{m}}$} & \multicolumn{3}{|c|}{ IPI } & \multicolumn{2}{c|}{ Hairiness } \\
\hline $\begin{array}{l}\text { Input } \\
\text { variables }\end{array}$ & Coeff. & $\mathbf{p}$-values & Coeff. & $\mathbf{p}$-values & Coeff. & $\mathbf{p}$-values & Coeff. & $\mathbf{p}$-values & Coeff. & $\mathbf{p}$-values \\
\hline $\begin{array}{l}X_{1}: \text { LD } \\
(\text { Tex })\end{array}$ & - & - & 0.04158 & 0.000 & - & - & - & - & 0.0767 & 0.000 \\
\hline $\begin{array}{l}X_{2}: \text { ST } \\
(\%)\end{array}$ & -62.89 & 0.000 & -0.2721 & 0.003 & 7.867 & 0.000 & $1-389.5$ & 0.000 & 0.3637 & 0.000 \\
\hline $\begin{array}{l}X_{3}: \text { SL } \\
(\mathrm{cm})\end{array}$ & -16.99 & 0.004 & - & - & 0.923 & 0.004 & - & - & - & - \\
\hline $\begin{array}{l}X_{4}: \mathrm{PL} \\
(\mathrm{cm})\end{array}$ & 54.47 & 0.000 & 0.1721 & 0.048 & - & - & -1196.9 & 0.000 & -0.2021 & 0.000 \\
\hline$X_{12}$ & - & - & - & - & - & - & - & - & - & - \\
\hline$X_{32}$ & 20.32 & 0.000 & 0.1686 & 0.035 & - & - & - & - & - & - \\
\hline$X_{42}$ & -20.29 & 0.000 & - & - & -1.321 & 0.000 & 464.5 & 0.000 & - & - \\
\hline$X_{1} X_{2}$ & - & - & - & - & - & - & - & - & - & - \\
\hline$X_{2} X_{3}$ & - & - & - & - & - & - & 377.9 & 0.001 & 0.1294 & 0.035 \\
\hline$X_{2} X_{4}$ & - & - & - & - & - & - & -1116.2 & 0.000 & - & - \\
\hline$X_{3} X_{4}$ & - & - & - & - & - & - & -211.7 & 0.039 & - & - \\
\hline
\end{tabular}

slub portions and the strength of slub portions starts to increase. This may be the reason of curvature effect of slub length and pause length on the overall yarn strength.

\subsubsection{Effect of Slub Parameters on Yarn Elongation}

Yarn elongation refers to a percentage increase in the length of the yarn before breaking. It was found from the statistical analysis (as given in Table 4) that the slub yarn elongation mainly depends on slub length (coeff. $=-0.881$ ) followed by yarn linear density (coeff. $=0.416$ ), pause length (coeff. $=0.0115$ ) and slub thickness (coeff. $=-0.0091$ ). Please see Figure 4 for illustration of effect of yarn count, pause length, slub thickness and slub length on the slub yarn's elongation. It is clear from the figure that slub yarn's elongation increases by increasing the yarn's linear density and pause length but decreases by increasing the slub thickness and slub length. The effect of slub length is not linear and this curvature effect is represented by the statistically significant square value $\mathrm{X}_{3}^{2}(\mathrm{P}$-Value $=0.035)$ as given in Table 5.

As the diameter of the yarn and number of fibers in the yarn cross section decrease with decrease in yarn linear density, the breaking elongation of yarn also decreases. [16]. During extension of staple yarn, every fiber within the yarn experiences differential tension depending on its radial position. The tension generated transverse force acts in the vertical direction of fiber axis, and causes frictional resistance to slippage and breakage. When tension generated on the gripped fiber reaches the fiber's breaking load, the fiber does not resist the stress any longer and breaks. If there are more number of fibers in the yarn cross section, there will be more frictional resistance to slippage and breakage because of more interaction and cohesive forces between the fibers.
The number of fibers in the slub portion is greater than the base yarn (pause portion), while the twist in the slub portion is less than the base yarn. As the yarn's elongation mainly depends on the twist of the yarn, [17] so by increasing the slub thickness and slub length, the twist in the slub portion decreases, due to which yarn elongation also decreases. The strength of cotton yarn increases with increase of twist up to a certain point; beyond that point, strength and elongation of yarn decreases. When the twist in the base yarn reaches its maximum point, it shifts towards slub portions and the elongation of slub portions also starts increasing. This is the reason for curvature found in the effect on slub length (see Figure 4).

\subsubsection{Effect of Slub Parameters on Yarn Mass Variation (Unevenness)}

Unevenness of slub yarn mainly depends on slub length (coeff. $=0.461)$ followed by pause length (coeff. $=0.401$ ), slub thickness (coeff. $=0.2622$ ), and linear density (coeff. $=-00152$ ), as given in Table 4. Please see Figure 5 for the illustration of effect of yarn's linear density, pause length, slub thickness and slub length on the unevenness of slub yarn. It is clear that the unevenness increases by increasing the slub length, slub thickness and pause length, but decreases with increase in the yarn's linear density. Unevenness first increases up to a certain point, after that it decreases by increasing the pause length. This non-linear effect (curvature effect) is represented by the statistically significant square value $\mathrm{X}_{4}{ }^{2}(\mathrm{P}$-value $=0.000)$, as given in Table 5 . Unevenness is not affected by the small change in linear density, but if the change in liner density is bigger, then there may be significant change in the unevenness. 

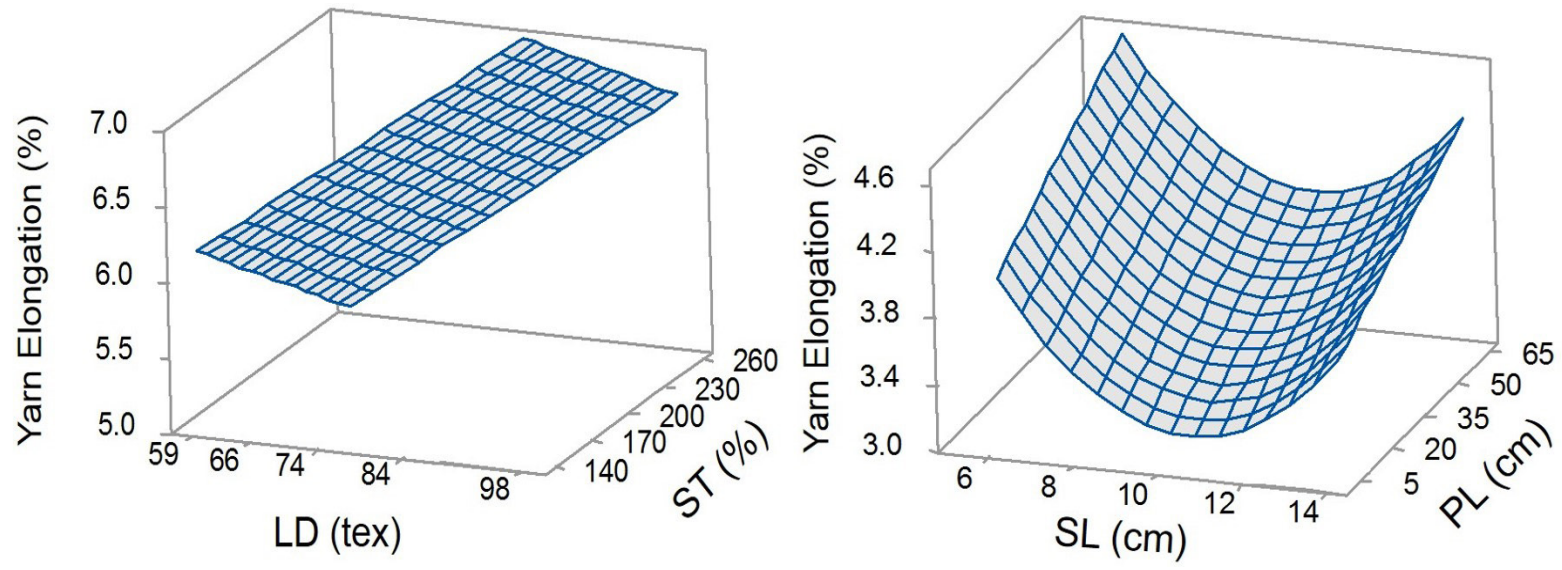

Figure 4. Response surface plot for elongation.
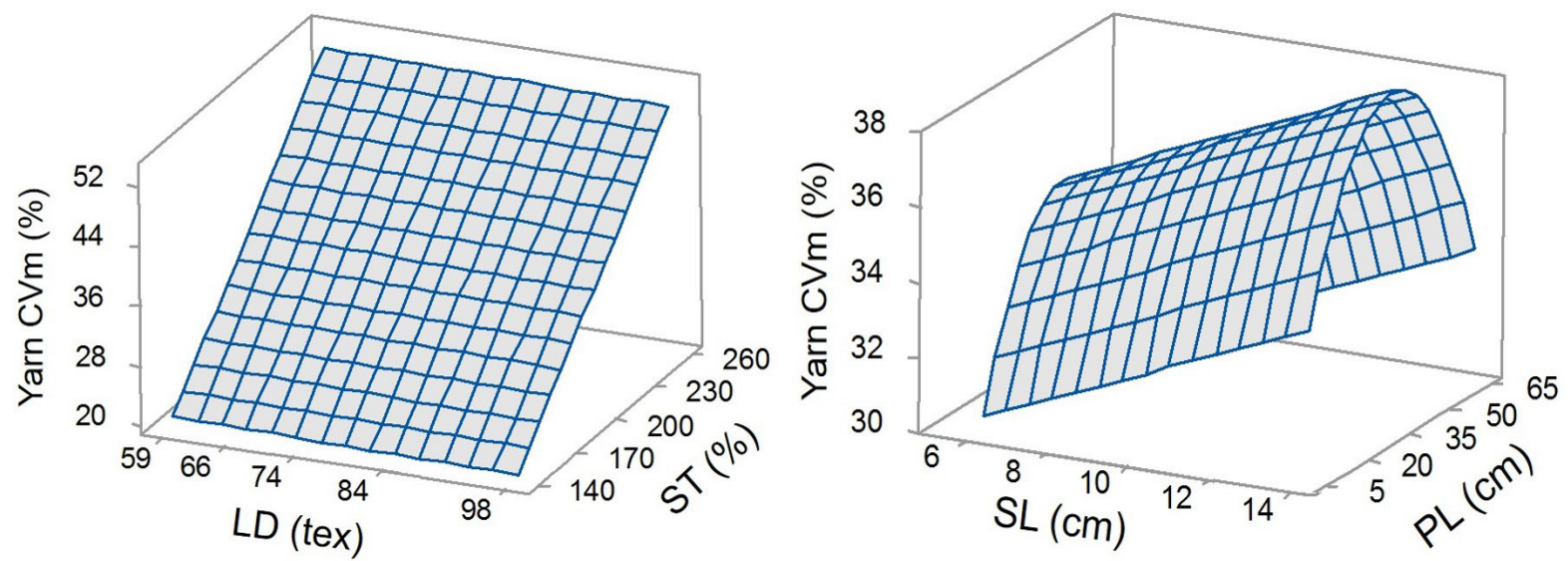

Figure 5. Response surface plots for $\mathrm{CV}_{\mathrm{m}}$.

One of the factors affecting the yarn unevenness is the number of fibers in the yarn cross section. Mass variation increases with decrease in yarn cross section and vice versa [18]. If the number of fibers in the yarn's cross section are less, slight variation in the thickness will be more prominent. As the slub thickness and slub length increases, there is more variation in the yarn's thickness resulting in more mass variation. Yarn unevenness also increases with increase in yarn's twist. So, unevenness increases initially with an increase in pause length because pause has more twist than slub portion. After a critical point, this twist starts to shift towards the slub portions and then unevenness starts to decrease.

\subsubsection{Effect of Slub Parameters on Yarn Imperfections (IPI)}

Imperfections are cumulative number of thick $+50 \%$, thin $-50 \%$ and neps $+200 \%$ per kilometer of yarn length. Total imperfections of slub yarn (IPI) mainly depend on slub length (coeff. $=-948.9$ ) followed by pause length (coeff. $=342.3$ ), slub thickness (coeff. = 70.1), and linear density (coeff. = -8.02), as given in Table 4. Please see Figure 6 for the illustration of effect of yarn linear density, pause length, slub thickness and slub length on the IPI of slub yarn. It is clear from the figure and table that imperfections increase by increasing slub thickness and slub length at low pause length but decrease with increase in pause length. The effect of pause length is not linear and this curvature effect is represented by the statistically significant square value $\mathrm{X}_{4}^{2}(\mathrm{P}$-value $=0.000)$ as given in Table 5 .

As the slub thickness increases, the number of thick places in the yarn increases and consequently, imperfections increase. As pause length in the yarn increases, the number of thick places (slubs) per kilometer of the yarn decreases, due to which imperfections decrease up to a certain point; after that, imperfections start to increase due to formation of neps because of less twist in the base yarn. Imperfections are not affected by a small change in the linear density, but if the change in liner density is bigger, then there may be a significant change in the IPI.

\subsubsection{Effect of Slub Parameters on Yarn Hairiness}

Yarn hairiness mainly depends on yarn slub length (coeff. = -0.403 ), followed by linear density (coeff. $=0.0767$ ), pause length (coeff. $=-0.0135$ ), and slub thickness (coeff. $=-0.0094$ ), as shown in Table 4. Please see Figure 7 for illustration of effect of yarn's linear density, pause length, slub thickness and slub length on the hairiness of slub yarn.

Hairiness characterizes the amount of fibers protruding from the yarn body. It decreases with a decrease in yarn's linear density [16] and increases with a decrease in slub thickness, slub length and pause length. This can be explained by the decrease in the twist in slub portion with an increase in the slub thickness, resulting in more protruding fibers and consequently, higher hairiness. Hairiness decreases with an increase in pause length due to higher twist in this portion, which results in a decrease in protruding fibers. 

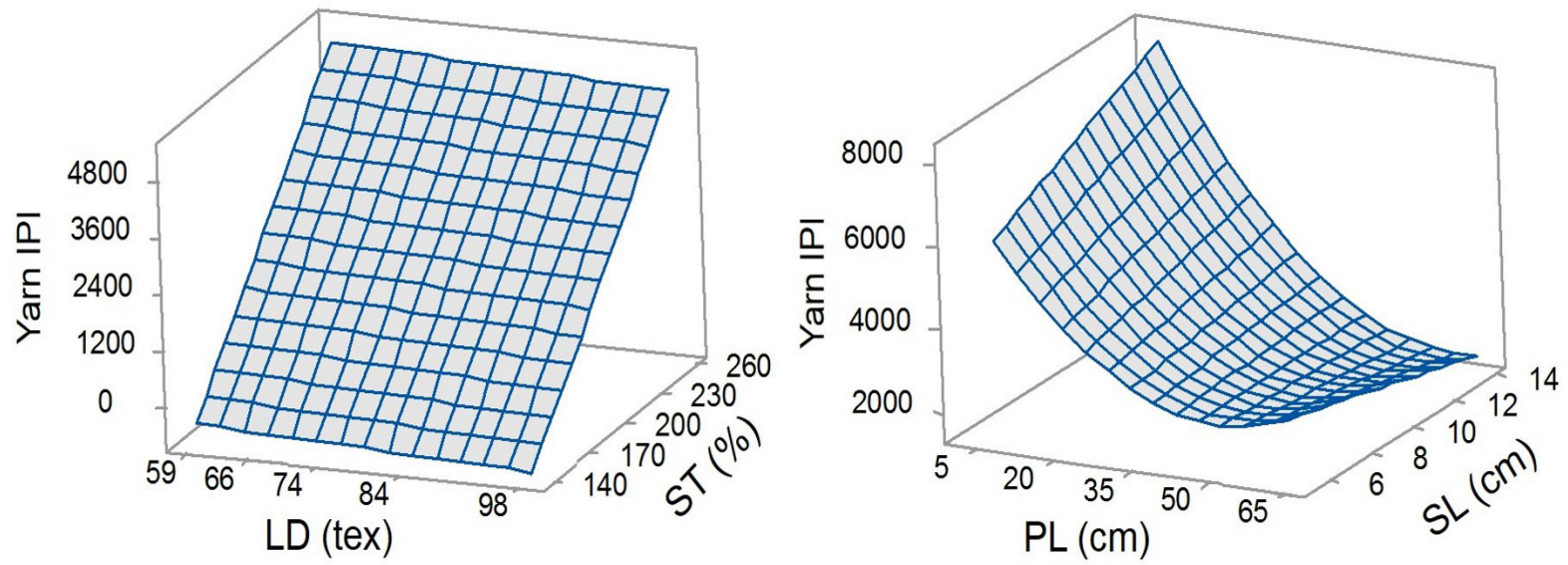

Figure 6. Response surface plots for imperfections.
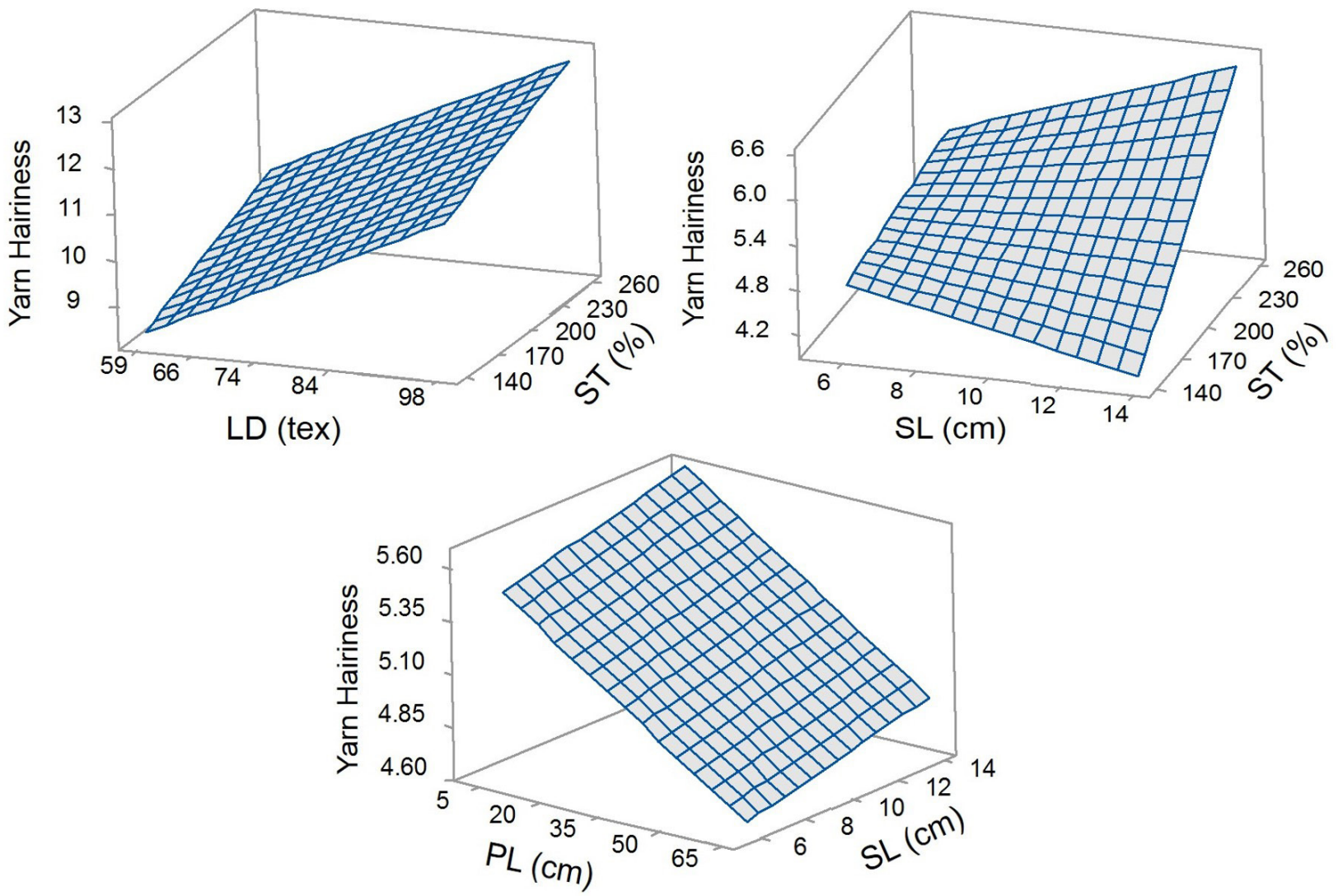

Figure 7. Response surface plots for hairiness.

The effect of interaction of slub length and slub thickness is not linear and this curvature effect is represented by the statistically significant interaction values of $\mathrm{X}_{2} \mathrm{X}_{3}$ (P-value $=$ 0.035), as given in Table 5. Hairiness decreases by decreasing the linear density of slub yarn, due to a better twist distribution in finer yarns (lower linear density). Again, hairiness reduces on increasing slub length at less slub thickness, but this phenomenon reverses at higher slub thickness. This trend may be attributed to higher twist at less slub thickness and vice versa.

\subsubsection{Validation of Models}

To validate the developed statistical models, eight set of experiments were chosen that were different than the sets used in central composite design. 120 bobbins of each experimental set were prepared and 20 bobbins were chosen randomly for sampling. A comparison of actual output yarn parameter values and those predicted by developed models is given in Table 6. Mean absolute error percentage of yarn parameters like slub yarn strength, elongation, unevenness, imperfections and hairiness is $3.2,7.3,3.7,8.5$ and 3.5 respectively, which indicate a very strong ability and accuracy of the predicted models.

\section{CONCLUSION}

The effect of four major slub yarn parameters, that is, yarn's linear density, slub thickness, slub length and pause length, was adequately modeled using the central composite experimental design of response surface methodology. It was concluded that an increase in the yarn's linear density results in an increase in yarn strength, elongation and hairiness, but 
Table 6. Comparison of predicted and actual values

\begin{tabular}{|c|c|c|c|c|c|c|c|c|c|c|c|c|c|c|c|c|c|c|c|}
\hline \multirow[b]{2}{*}{ Exp \# } & \multicolumn{4}{|c|}{ Input Variables } & \multicolumn{3}{|c|}{ Strength } & \multicolumn{3}{|c|}{ Elongation } & \multicolumn{3}{|c|}{$\mathrm{CV}_{\mathrm{m}}$} & \multicolumn{3}{|c|}{ IPI } & \multicolumn{3}{|c|}{ Hairiness } \\
\hline & LD & ST & SL & PL & Pred. & Act. & $\begin{array}{c}\% \\
\text { Diff. }\end{array}$ & Pred. & Act. & $\%$ Diff. & Pred. & Act. & $\begin{array}{c}\% \\
\text { Diff. }\end{array}$ & Pred. & Act. & $\begin{array}{c}\% \\
\text { Diff. }\end{array}$ & Pred. & Act. & $\begin{array}{c}\% \\
\text { Diff. }\end{array}$ \\
\hline 1 & 84.4 & 200 & 12 & 35 & 1100 & 1130 & $-2.6 \%$ & 6.79 & 6.2 & $9.5 \%$ & 37.1 & 37.9 & $-2.1 \%$ & 2371 & 2029 & $16.9 \%$ & 11.1 & 10.7 & $3.8 \%$ \\
\hline 2 & 73.9 & 230 & 10 & 50 & 929 & 910 & $2.0 \%$ & 6.20 & 5.85 & $6.0 \%$ & 42.6 & 43.7 & $-2.6 \%$ & 1785 & 1913 & $-6.7 \%$ & 10.3 & 10.0 & $3.4 \%$ \\
\hline 3 & 65.7 & 170 & 8 & 20 & 876 & 925 & $-5.3 \%$ & 6.24 & 6.61 & $-5.7 \%$ & 26.9 & 28.3 & $-5.0 \%$ & 1438 & 1321 & $8.9 \%$ & 9.6 & 10.1 & $-4.8 \%$ \\
\hline 4 & 73.9 & 200 & 12 & 20 & 887 & 870 & $1.9 \%$ & 6.21 & 5.5 & $13.0 \%$ & 35.3 & 37.5 & $-6.0 \%$ & 4245 & 3808 & $11.5 \%$ & 10.4 & 10.9 & $-4.2 \%$ \\
\hline 5 & 98.5 & 200 & 10 & 35 & 1280 & 1255 & $2.0 \%$ & 7.10 & 7.8 & $-9.0 \%$ & 36.2 & 35.5 & $1.9 \%$ & 2243 & 2138 & $4.9 \%$ & 12.2 & 11.9 & $2.5 \%$ \\
\hline 6 & 59.1 & 200 & 10 & 35 & 811 & 850 & $-4.6 \%$ & 5.50 & 5.7 & $-3.6 \%$ & 36.2 & 37.1 & $-2.5 \%$ & 2243 & 2230 & $0.6 \%$ & 9.3 & 9.6 & $-2.7 \%$ \\
\hline 7 & 59.1 & 260 & 14 & 65 & 718 & 752 & $-4.5 \%$ & 5.79 & 5.22 & $11.0 \%$ & 50.8 & 49.8 & $2.1 \%$ & 947 & 1045 & $-9.4 \%$ & 9.9 & 10.2 & $-3.3 \%$ \\
\hline 8 & 98.5 & 140 & 6 & 35 & 1477 & 1440 & $2.5 \%$ & 8.45 & 8.55 & $-1.2 \%$ & 18.6 & 17.4 & $7.1 \%$ & 720 & 658 & $9.4 \%$ & 11.5 & 11.1 & $3.3 \%$ \\
\hline & & & & & $\%$ Мег & Err & $3.2 \%$ & $\% \mathrm{Me}$ & Error & $7.3 \%$ & $\% \mathrm{Me}$ & Error & $3.7 \%$ & $\% \mathrm{M}$ & Error & $8.5 \%$ & $\% \mathrm{M}$ & Error & $3.5 \%$ \\
\hline
\end{tabular}

a decrease in unevenness and imperfections. An increase in the slub thickness and slub length results in a decrease in yarn strength, elongation and hairiness, but an increase in yarn $\mathrm{CV}_{\mathrm{m}}$. An increase in pause length results in increasing the yarn strength, elongation, $\mathrm{CV}_{\mathrm{m}}$ and $\mathrm{IPI}$, but a reduction in yarn hairiness. It was further found that the effect of yarn's linear density on yarn strength is not linear. Similarly, the effect of slub length on yarn strength and elongation is not linear, and the effect of pause length on yarn strength, $\mathrm{CV}_{\mathrm{m}}$ and IPI also has a curvature effect. Furthermore, in case of IPI, there is a statistically significant interaction between slub thickness and slub length, between slub thickness and pause length, and between slub length and pause length. Similarly, in case of yarn strength and hairiness, there is a significant interaction between slub thickness and slub length. These all results lead towards a concrete fundamental of modelling of fancy yarns.

\section{REFERENCES}

[1] Petrulytè, S., (2003). Complex Structure Fancy Yarns: Theoretical and Experimental Analysis. Materials Science (Medžiagotyra), 9(1), 120-123.

[2] Kwasniak, J., (1997). Application of a pressurized-air method of fancy-yarn formation to industrial rotor-spinning machines. Journal of the Textile Institute, 88(3), 185-197.

[3] Kwasniak, J. and Peterson, E., (1997). The formation and structure of fancy yarns produced by a pressurized-air method. Journal of the Textile Institute, 88(3), 174-184.

[4] Grabowska, K. E., Ciesielska, I. L., and Vasile, S., (2009). Fancy yarns-an appraisal. AUTEX Research Journal, 9(3), 74-81.

[5] Souid, H., Babay, A., Sahnoun, M., and Cheikrouhou, M., (2008). A comparative quality optimization between ring spun and slub yarns by using desirability function. AUTEX Research Journal, 8(3), 72-76.

[6] Kim, G., (2012). Woven Textiles: Principles, Developments and Applications: Woodhead Publishing Limited.

[7] Xiuping, L., Zhijie, W., Zhixun, S., and Choi, K. F., (2008). Slub Extraction in Woven Fabric Images Using Gabor Filters. Textile Research Journal, 78(4), 320-325.
[8] Testore, F. and Minero, G., (1988). A Study of the Fundamental Parameters of Some Fancy Yarns. The Journal of The Textile Institute, 79(4), 606-619.

[9] Lu, Y., Gao, W., and Wang, H., (2007). A model for the twist distribution in the slub $\square$ yarn. International Journal of Clothing Science and Technology, 19(1), 36-42.

[10] Jun, W. and Xiubao, H., (2002). Parameters of Rotor Spun Slub Yarn. Textile Research Journal, 72(1), 12-16.

[11] (January 12). USTER, Fancy Yarn Profile. Available: http:// www.uster.com/en/instruments/yarn-testing/uster-testerstaple-yarn

[12] Jihong, L., Zhenping, X., Weidong, G., and Hongxia, J., (2009). Automatic Determination of Slub Yarn Geometrical Parameters Based on an Amended Similarity-based Clustering Method. Textile Research Journal, 80(11), 1075-1082.

[13] Chattopadhyay, R. and Sinha, S., (2007). A study on spinning limits and yarn properties with progressive change in yarn count in friction spinning. AUTEX Research Journal, 7(1), 1-8.

[14] M.D. Teli, A.R. Khare, and Chakrabarti, R., (2008). Dependence of yarn and fabric strength on the structural parameters. AUTEX Research Journal, 8(3), 63-67.

[15] Dominika Rosiak and Przybyt, K., (2004). Twisting of multifolded yarns and threads manufactured by means of new spinning technologies. AUTEX Research Journal, 4(3), 113-117.

[16] Ureyen, M. E. and Kadoglu, H., (2007). The prediction of cotton ring yarn properties from AFIS fibre properties by using linear regression models. Fibres and Textiles in Eastern Europe, 15(4), 63-67.

[17] Ishtiaque, S., Das, B., Kumar, A., and Ramamoorthy, M., (2008). Static and dynamic failure mechanisms of cotton yarns. Indian Journal of Fibre \& Textile Research, 33(1), 111-118.

[18] Ahmad, I., Nawaz, S. M., and Tayyab, M., (2004). Interaction study of staple length and fineness of cotton with ultimate yarn regularity and hairiness. Journal of Applied Sciences, 4(1), 48-52. 